\title{
التتتاصية العددد
}

يطيب لأسرة تحرير المجلة العلمية لكلية الدراسات الاقتصادية والعلوم السياسية بجامعة

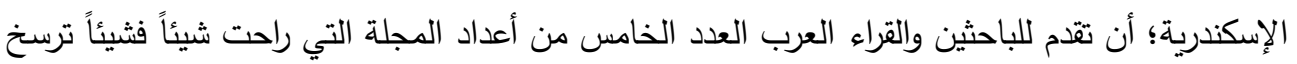
أقدامها بين نظيراتها العربيات كدورية علمية محكمة متخصصة في الإنئ مجالي الاقتصاد والعلوم السياسية،

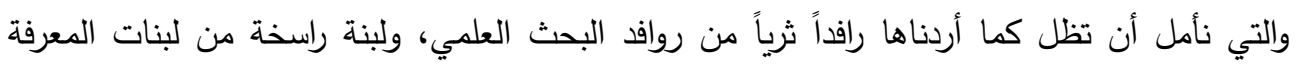

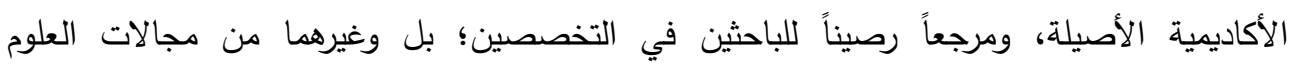

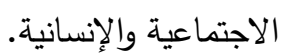

ويشتمل هذا العدد الخامس من أعداد المجلة على ست دراسات هامة ومتتوعة؛ تتثل أولاها

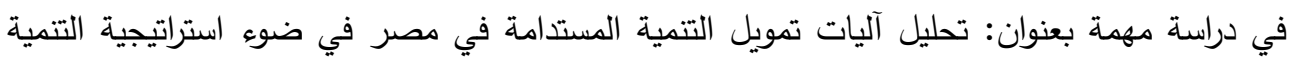

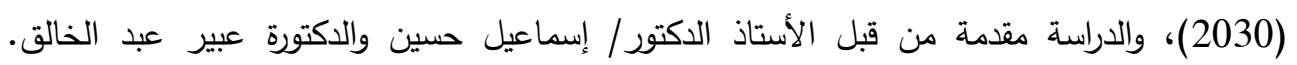

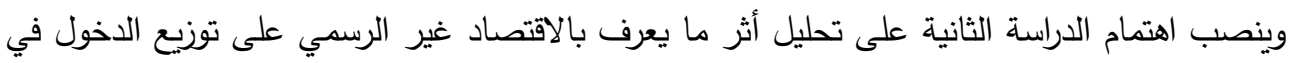

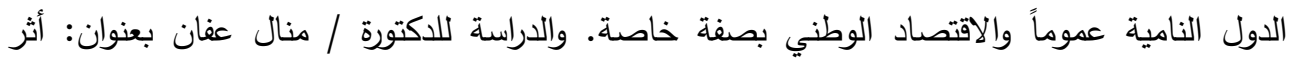

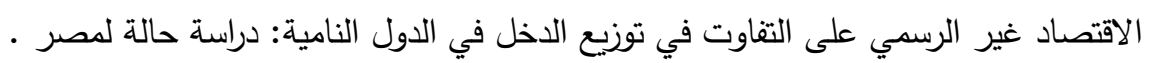

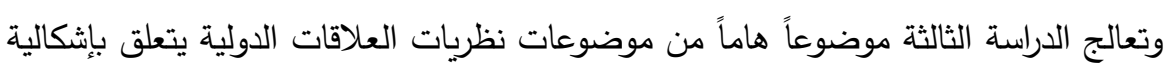

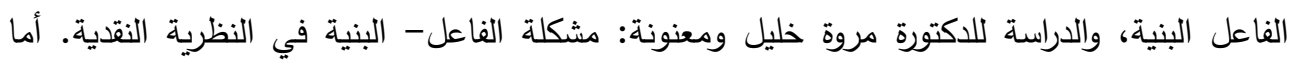

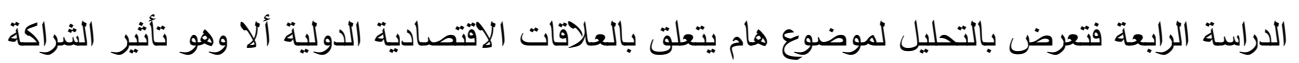

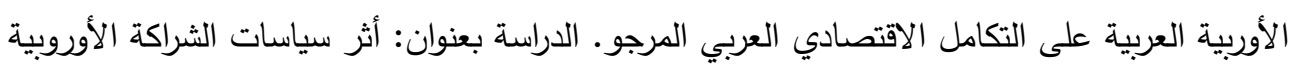
- العربية في العمل الاقتصادي العربي المشترك (من 1957م إلى لعى 2014م)، وهي مقدمة من الدكتورة

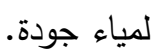
وتمثل الدراسـة الخامسـة استعراضـاً للـرؤى التنظيريـة المختلفة لظـاهرة الاستقرار في الأنسـاق

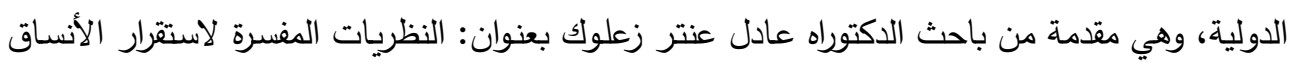

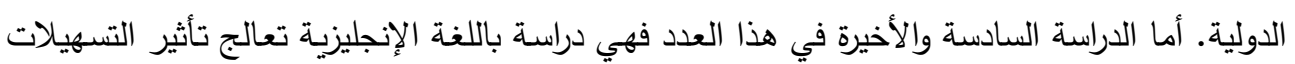

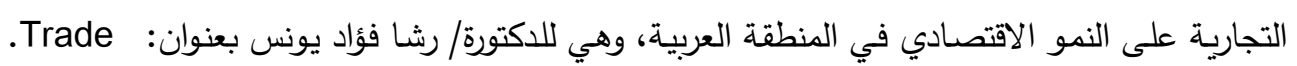

Facilitation and Economic Growth (Arab Region)

وفي النهاية؛ فإننا إذ نضع هذا العدد بين يدي القارئ والباحث العربي نأمل أن يمثل إضافة

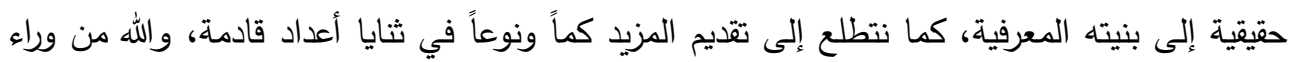
القصد.

رئيس التحرير

أ.د. أحمد محمد وهبان 